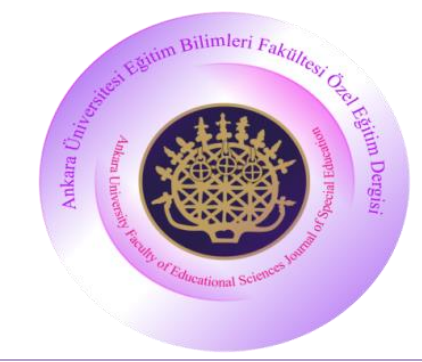

\section{Ankara Üniversitesi Eğitim Bilimleri Fakültesi Özel Eğitim Dergisi}

Yıl: 2018, Cilt: 19, Sayı: 2, Sayfa No: 257-275

DOI: 10.21565/ozelegitimdergisi.372512

\title{
Grupla Psikolojik Danışma Uygulamasının Özel Gereksinimli Çocuğu Olan Annelerin Kaygı Düzeyleri ve Yaşam Doyumları Üzerindeki Etkisinin İncelenmesi*
}

\author{
Nermin Çiftçi Arıdă (iD** \\ Yıldız Teknik Üniversitesi
}

\author{
Eyüp Sabır Erbiçer iD *** \\ Yıldız Teknik Üniversitesi
}

\begin{abstract}
Öz
Bu araştırmanın amacı, özel gereksinimli çocuğa sahip annelere uygulanan grupla psikolojik danışma programının, annelerin durumluk-sürekli kaygı düzeylerinin azalmasında, yaşam doyumlarının ise artmasında etkili olup olmadığını incelemektir. Çalışma, özel eğitime gereksinimi olan ve Milli Eğitim Bakanlığı'na bağlı özel bir rehabilitasyon merkezine devam eden 3-17 yaşları arasındaki çocukların anneleri ile yürütülmüştür. Ön test-son test kontrol gruplu deneysel modelin kullanıldığı çalışmada deney ve kontrol grubunda sekiz anne olmak üzere toplam 16 anne katılmıştır. Uygulama grubunda yer alan annelere sekiz oturumdan oluşan grupla psikolojik danışma programı uygulanmıştır. Veriler Durumluk-Sürekli Kaygı Envanteri (State-Trait Anxiety Inventory) ve Yaşam Doyumu Ölçeği (Satisfaction with Life Scale) ile toplanmıştır. Verilerin analizinde Kovaryans (ANCOVA) analizi kullanılmıştır. Grupla psikolojik danışma uygulaması sonucundadeney grubundaki annelerin durumluksürekli kaygı puanlarında kontrol grubuna göre anlamlı düzeyde azalma olduğu saptanmıştır. Annelerin, yaşam doyumlarında ise anlamlı düzeyde artma olduğu gözlenmiştir.
\end{abstract}

Anahtar sözcükler: Grupla psikolojik danışma, kaygı, durumluk kaygı, sürekli kaygı, yaşam doyumu, özel gereksinimli çocuk anneleri, özel gereksinimi olan çocuklar.

\section{Önerilen Atıf Sekli}

Çiftçi Arıdağ, N., \& Erbiçer, E. S. (2018). Grupla psikolojik danışma uygulamasının özel gereksinimli çocuğu olan annelerin kaygı düzeyleri ve yaşam doyumları üzerindeki etkisinin incelenmesi. Ankara Üniversitesi Eğitim Bilimleri Fakültesi Özel Eğitim Dergisi, 19(2), 257-275. doi: 10.21565/ozelegitimdergisi.372512

\footnotetext{
*Bu makale 14-17 Eylül 2016 tarihleri arasında yapılan 9. Türk-Alman Psikiyatri kongresinde poster bildiri olarak sunulmuştur. **Sorumlu yazar: Dr. Öğrt. Üyesi, E-posta: nermin_ciftci@ yahoo.com, https://orcid.org/0000-0002-1993-8352

${ }^{* * *}$ Araş.Gör., E-posta: sabirerbicer@ hotmail.com, https://orcid.org/0000-0001-8253-7212
} 
Bütün toplumlarda çocuklar, geleceğin yetişkini olarak görülür ve özenle yetiştirilir. Aileler çocukları için ellerindeki olanaklarını en üst düzeyde kullanmaya çabalarlar. Çocukların, büyüme sürecinde gereksinimlerinin karşılanması önemlidir. Annenin gebeliğinin anlaşılması ile birlikte aileye katılacak olan birey için yoğun bir hazırlık başlar. Tüm toplumlarda farklı tutum ve alışkanlıklar olmakla birlikte, ortak nokta çocuğun sağlığı için anneye gösterilen özendir. Çocuğun doğumuyla birlikte ailenin hayatı yeni bir yön kazanacaktır (Yıldırım Doğru ve Arslan, 2008). Aile sağlıklı bir çocuk beklerken, çocuğun özel gereksinimli olması ailenin bütün beklentilerini değiştirecektir. Özel gereksinimli çocukları olan aileler, diğer ailelerin karşılaştıkları baskılara ve gerilimlere ek olarak, çocuklarının özel sorunları ve gereksinimleri nedeniyle çeşitli güçlükler yaşamaktadırlar (Gallagher, Beckman ve Cross, 1983). Aileler, bu yoğun stresli, uzun süreli sorunla baş etmede yetersiz kalabilir ve çeşitli duygusal ve davranışsal sorunlar yaşayabilirler (Yıldırım ve Conk, 2005). Alan yazındaki çalışmalar genel olarak özel gereksinimli çocuğa sahip anne-babaların diğer anne-babalara göre daha fazla kaygı yaşadıklarını ortaya koymaktadır (Dilmaç, Çıkılı, Koçak ve Çalıkçı, 2015; Esdaile ve Greenwood, 2003; Hastings, 2003; Uğuz, Toros, İnanç ve Çolakkadıŏglu, 2004).

Öner (1997) kaygıyı, bireyin tehlikeli ya da tehdit edici olarak algıladığı, etkilerinin hoş olmadığını düşündüğü çevresel kaynaklı bir uyarıcıya bağlı olan ve bireyde oluşan bir ruh hali olarak tanımlamıştır. Erol ve Öner'e (1999) göre kaygı, yaygın, rahatsız edici ve süreklidir. Açık olarak nedeni belirlenemez ve kontrol edilemez. Başlangıcı ve bitişi belli değildir. Durumluk kaygı ise, bireyin içinde bulunduğu kaygılı durumdan dolayı hissettiği öznel korkudur. Fizyolojik olarak da, otonom sinir sisteminde meydana gelen bir uyarılma sonucu terleme, sararma, kızarma ve titreme gibi fiziksel değişimler, bireyin gerilim ve huzursuzluk duygularının göstergeleridir. Sürekli kaygı ise bireyin kaygı yaşantısına olan yatkınlığıdır. Buna, kişinin içinde bulunduğu durumları, genellikle stresli olarak algılama ya da kaygı verici olarak yorumlama eğilimi de denilebilir. Nesnel kriterlere göre nötr olan durumların, birey tarafından tehlikeli ve özünü tehdit edici olarak algılanması sonucu oluşan hoşnutsuzluk duygusu, sürekli kaygı olarak tanımlanır. Bu tür kaygı seviyesi yüksek olan bireylerin kolaylıkla incindikleri ve karamsarlığa büründükleri görülür (Öner ve Le Compte, 1985). Sarason'a (1988) göre kaygı, bireyin kendisini güvensiz hissettiği durumlar karşısında gösterdiği bir tepki olarak endişe, kararsızlık, karmaşa, korku, kötümserlik ve umutsuzluk duygularını ifade etmekte, dolayısıyla fiziksel, duygusal ve sosyal yönlerden bireyin iyi oluş düzeyini olumsuz yönde etkileyebilmektedir.

İnsanların nihai hedeflerinden birisi olarak görülen ve mutluluğun bir alt boyutu olarak değerlendirilen yaşam doyumu, yaşam kalitesiyle paralellik gösteren, yaşam kalitesini olumlu veya olumsuz etkileyen önemli faktörlerdendir. Bu anlamda insanların fiziksel fonksiyonları, psikolojik durumları, aile içinde ve dışındaki sosyal ilişkileri, sosyal çevre etkileşimleri ve inançları yaşam doyumunda önemli bir yer tutar (Dilmaç ve Ekşi, 2008). Ayrıca yaşam koşullarının iyi olması, bireyin kendisini mutlu hissetmesi ve başkalarına bağımlı olmadan yaşamını devam ettirip işlerini yaparak yaşamın rahatlığına ulaşması, önemli bir yaşam doyumu belirtisidir. Yaşam doyumunda bireyler sadece kendi yaşam tarzlarını ve kalitesini geliştirmekle kalmazlar. Bunun yanında psikolojik ve ekonomik yönden bireyi etkileyebilecek muhtemel durumlar vardır. Kişinin sorumluluğunda bulunan aile bireylerinin yaşam kalitesi de yaşam doyumunda önemli bir etkendir. Yaşam doyumu genel olarak kişinin bütün yaşamını ve bu yaşamın tüm boyutlarını içerdiği gibi mutluluk, moral gibi değişik açılardan iyi olma halini de ifade eder (Koçoğlu, 2006). Köker'e (1991) göre yaşam doyumu bireyin iş, serbest zaman ve diğer zaman dilimlerindeki yaşamına gösterdiği duygusal tepki veya tutumdur. Yaşam doyumu; yaş, cinsiyet, çalışma ve iş koşulları, eğitim seviyesi, gelir düzeyi, aile yaşamı, toplumsal yaşam, kişilik özellikleri ve biyolojik etkenlerle ilişkilidir. Deniz'e (2006) göre, sağlıklı karar alma ve kaygıyla başa çıkma yaşam doyumu seviyesini artırabilir. Bilge ve diğerleri (2014) tarafindan yapılan çalışmada, kaygı azaldıkça yaşam doyumunun arttığı görülmektedir. Ayrıca Kaner (2004), yaşam doyumunun farklı türdeki sosyal desteklerle ilişkili olduğunu, anne-babaların yaşamlarını kolaylaş̧ıran desteklere sahip olduklarında, yaşam doyumlarının daha yüksek ve kaygılarının daha az olduğunu belirtmiştir.

Özel gereksinimli çocuğu olduğunu öğrenen aileler, kaygı verici pek çok durumu beraberinde yaşarlar. Aileler için çocuklarının problemlerini öğrenme biçimleri kadar çocuğun hangi yetersizliğe sahip olduğunu 
öğrenmeleri de önemlidir. Aileler, çocuklarının özel gereksinimi olduğunu öğrendiğinde, bundan kendilerini sorumlu tutabilirler (Dilmaç ve diğ., 2015). Normal gelişim gösteren bir çocuk anne-baba için "Bakın ne kadar iyiyim!" mesajını çevreye iletirken, özel gereksinimli bir çocuk "Başaramadım, iyi değilim!" mesajıyla annebabada mutsuzluk ve hayal kırıklı̆ğ, başarısızlık duygularına yol açabilir. Bu durum özellikle anneyi daha fazla etkileyebilir (Deniz, Dilmaç ve Arıcak, 2009). Sağlıklı bir çocuğa sahip olma beklentisi içindeki aile, böylesi bir gerçekle karşılaşınca inkâr etme, öfke, pazarlık, mucize arama ve çocuğu reddetme gibi durumlar yaşayabilir. Böyle bir kaybı ve hayallerinin ölümünü reddeden aile, çözümlenmemiş, bitmemiş bir yas sürecine girebilir (Fışıloğlu ve Fışıloğlu, 1997). Cameron, Dobson ve Day'a (1991) göre, bazı anneler bu süreçte şok olmuş, inancını kaybetmiş, sinirli, reddedici ve suçlu hissederken, bazıları ise korku, kayıp duygusu ve kızgınlık hissedebilirler.

Özel ihtiyaçları nedeniyle özel bakım ve eğitim gerektiren bir çocuğa sahip olmak, aile için elbette pek çok zorluğun varlığını içerir. Özel gereksinimli çocuğun olması aile yaşamına sınırlılık getirebilir. Ömür boyu bakım, sürekli hastalık kaygısı, maddi kaygılar, beklenen çocuktan farklı çocuğa sahip olma gibi durumlar aileler üzerinde yoğun baskı ve sıkıntı yaratır. Bunun yanı sıra aile "Ne yapılacak?" Nasıl çözüm bulunacak?” gibi soru ve sorunlarla baş etme yolları da aramak zorundadır. Ayrıca ebeveynler çocuklarının bağımlılığının, onların sonraki yaşamlarını nasıl etkileyeceğini de düşünmek zorundadırlar. Aileler, "Çocuklarının gelecekteki yaşantıları ne olacak?", "Kendileri çocuklarına bakamayacak duruma geldiklerinde çocuklarına kim bakacak?" sorularına yanıt aramak zorunda kalabilirler. Bu durum ebeveynlerin çocuklarının geleceği ile ilgili kaygılarını artırabilmekte ve yaşam doyumunu engelleyen bir tehdit olarak algılanabilmektedir (Bilge ve diğ., 2014; Doğru ve Arslan, 2008). İlgili alanyazındaki çalışmalar genel olarak, özel gereksinimli çocuğu olan ailelerin stres ve kaygı düzeylerinin normal gelişim gösteren çocuğa sahip ebeveynlere göre daha yüksek olduğunu göstermektedir (Baker-Ericzén, Brookman-Frazee ve Stahmer, 2005; Kazak ve Marvin, 1984). Özel gereksinimli çocuğu olan bazı ailelerde annelerin normal gelişim gösteren çocuklara göre daha fazla kaygı yaşadıkları gözlenmiştir (Beckman, 1983; Bradshaw ve Lawton, 1978; Burden, 1980; Akt., Byrne ve Cunningham, 1985). Wishart, Bidder ve Gray'in (1981) yaptığı çalışmada da, özel gereksinimli çocuğa sahip annelerin kaygı düzeylerinin normal gelişim gösteren çocukların annelerine göre daha yüksek olduğu saptanmıştır.

Yukarıda belirtilen nedenlerden dolayı özel gereksinimli çocuğa sahip aileler psikolojik ve sosyal desteğe, diğer ailelerden daha fazla ihtiyaç duyarlar (Cin ve Kılıç, 2005). Sosyal destek hizmetleri ailelerin kaygılarını azaltmada ve yaşam doyumlarını arttırmada önemli bir etmendir (Cameron ve Armstrong, 1991; Kaner, 2004). Ailelere sunulacak yardım hizmetleri, özel gereksinimli çocuğa sahip anne-babaların kendilerine ve çocuklarına ilişkin duygu, düşünce, algı ve beklentilerine, çocuklarını kabul etmelerine, gelecek için umutlarını yeniden ve gerçekçi olarak belirlemelerine katkı sağlayabilmektedir (Ersanlı ve Kutlu, 1998). Sosyal destek hizmetlerinin özel gereksinimli çocuğu olan ailelerin kaygılarında önemli düzeyde düşüş sağladığı saptanmıştır (Cin, 2001; Ersoy ve Güneysu, 1998; Tamer, 2010). Deniz, Dilmaç ve Arıcak'ın (2009) yaptığı çalışmada, destek eğitim grubuna katılan özel gereksinimli çocuğu olan annelerin eğitim sonunda kaygı düzeylerinin azaldığı ve yaşam doyumu düzeylerinin arttığı gözlenmiştir.

Profesyonel bir hizmet olan psikolojik danışma ve rehberlik hizmetleri geniş bir kapsamı içermekte olup, bilgi verici hizmetlerden psikolojik danışma hizmetlerine kadar farklı alanları içermektedir (Kuzgun ve Hamamcı, 2007). Bu alanlardan bir tanesi de grupla psikolojik danışma uygulamalarıdır. Stewart'a göre (1986), danışma oturumlarında, anne-babaların çocuklarıyla etkileşime girmelerine, aile içi uyumu sağlayabilmelerine ve bütünüyle fonksiyonel bireyler olmalarına yardım edilir (Akt., Küçüker, 1993). Özel gereksinimi olan çocuğun tüm aile bireyleri üzerinde etkisi vardır. Bu nedenle yardım ilişkisinde özel gereksinimli çocuğu olan annelerle çalışmak demek, aynı zamanda tüm aileye de yardım etmek demektir. Özel gereksinimli çocuğa sahip annelere psikolojik danışmanlık desteğinin sağlanması, onların ihtiyaç duydukları destek gereksinimini karşılayabilmeleri, zamanla çocuklarının durumunu kabullenip, çocuklarının gelişimive eğitimi için gerekli olanları yapmalarını sağlayabilmeleri, çocuklarının ihtiyacı olan ilgi ve sevgiyi onlara vererek kendilerinin yeni yaşamlarına uyum sağlamaları, stresleriyle baş edebilmeleri, çocukları ve çevreleri ile sağlıklı ilişkiler kurmaları açısından önemlidir (Özokçu ve Canpolat, 2013). 
$\mathrm{Bu}$ nedenlerle bu çalışmada, özel gereksinimli çocuğa sahip annelerle çalışılmıştır. Bu kapsamda, annelerle sekiz oturumluk grupla danışma uygulaması gerçekleştirilmiştir. Amacımız, farklı engel gruplarındaki çocuğa sahip anneleri bir araya getirerek, annelerin grup desteği ve empati duygusu ile birbirlerini desteklemelerini sağlamaktır. Bu bağlamda, grupla psikolojik danışma oturumlarında, çocukların engel düzeylerini ve engelin özelliklerini dikkate almaksızın, annelerin başa çıkma düzeylerini desteklemek amacıyla grupla danışma uygulaması gerçekleştirilmiştir. Mevcut çalışmada, özel gereksinimi olan çocuğa sahip annelere uygulanacak grupla psikolojik danışma programının temel amacı, annelerin durumluk-sürekli kaygı düzeylerini azaltmak ve yaşam doyumlarını artırmaktır.

$\mathrm{Bu}$ araştırmanın genel amacına uygun olarak aşağıda belirtilen denenceler test edilmiştir:

- Durumluk kaygı öntest puanları kontrol edildiğinde, grupla psikolojik danışma programına katılan ve katılmayan annelerin sontest durumluk kaygı puanları ortalaması anlamlı olarak farklıdır.

- Sürekli kaygı öntest puanları kontrol edildiğinde, grupla psikolojik danışma programına katılan ve katılmayan annelerin sontest sürekli kaygı puanları ortalaması anlamlı olarak farklıdır.

- Yaşam doyumu öntest puanları kontrol edildiğinde, grupla psikolojik danışma programına katılan ve katılmayan annelerin sontest yaşam doyumu puan ortalaması anlamlı düzeyde farklıdır.

\section{Yöntem}

\section{Araştırma Modeli}

$\mathrm{Bu}$ araştırmada özel gereksinimli çocuğa sahip annelere uygulanan grupla psikolojik danışma programının, annelerin durumluk-sürekli kaygı düzeyleri ve yaşam doyum düzeyleri üzerindeki etkisi incelenmiştir. Çalışmada ön test-son test kontrol gruplu deneysel model kullanılmıştır (Karasar, 2015). Araştırmada uygulanan deneysel model Tablo 1'de sunulmuştur.

Tablo 1

Araştırmada Uygulanan Deneysel Model

\begin{tabular}{lccc}
\hline Gruplar & Ön test & Uygulama & Sontest \\
\hline $\begin{array}{l}\text { Deney } \\
\text { Grubu }\end{array}$ & Durumluk-Sürekli Kaygı Envanteri & Grupla PsikolojikDanışma & Durumluk-Sürekli Kaygı Envanteri \\
Kontrol & Yaşam Doyumu Ölçeği & Programı & Yaşam Doyumu Ölçeği \\
Grubu & Yaşam Doyumu Ölçeği & İşlem yok & Durumluk-Sürekli Kayğ Envanteri \\
\end{tabular}

\section{Çalışma Grubu}

Bu araştırma, 2016 yılında İstanbul'un bir ilçesinde Milli Eğitim Bakanlığı'na bağlı özel bir özel eğitim ve rehabilitasyon merkezinde eğitim alan özel gereksinimli çocukların anneleri ile yürütülmüştür.

Çalışma grubunun oluşturulması için grupla psikolojik danışma programına katılmak isteyen annelere "DurumlukSürekli Kaygı Envanteri” ve "Yaşam Doyumu Ölçeği” uygulanmıştır. "Durumluk-Sürekli Kaygı Envanteri”nden en yüksek, "Yaşam Doyumu Ölçeği”"nden en düşük puan alan 16 anne arasından seçkisiz atama yöntemiyle 8'er kişilik deney ve kontrol grubu oluşturulmuştur. Deney grubundaki annelere yönelik grupla psikolojik danışma uygulaması, yüksek lisans programı öğrencisi olan ikinci yazar tarafindan "Grupla Psikolojik Danışma Uygulamaları” dersi kapsamında birinci yazarın süpervizyonunda yürütülmüştür. Grupla psikolojik danışma programına katılacak annelerin sayısının belirlenmesinde, Voltan-Acar'ın (2015), yüksek lisans ve doktora öğrencilerinin, uygulama dersleri gereği, grup lideri deneyimi kazanma süreçlerinde 7-12 üyeden oluşan grup oluşturmaları ile ilgili önerileri dikkate alınmıştır. Tablo 2'de deney ve kontrol grubunda yer alan katılımcıların demografik özelliklerine ilişkin bilgiler sunulmuştur. 
Tablo 2

Deney ve Kontrol Grubunda Yer Alan Katılımcıların Demografik Özelliklere Göre Dă̆ılımı

\begin{tabular}{|c|c|c|c|}
\hline Değişkenler & & $\mathbf{N}$ & $\%$ \\
\hline \multirow{8}{*}{ Çocuğun Engel Durumu } & Otizm & 7 & 43.7 \\
\hline & Fenilketonüri & 1 & 6.2 \\
\hline & Down Sendromu & 2 & 12.5 \\
\hline & İşitme Engeli & 1 & 6.2 \\
\hline & Bedensel Engeli & 1 & 6.2 \\
\hline & Konuşma Engeli & 2 & 12.5 \\
\hline & Zihinsel Engeli & 1 & 6.2 \\
\hline & Serebral Palsi & 1 & 6.2 \\
\hline \multirow{4}{*}{ Çocuğun Yaşı } & $3-6$ yaş & 5 & 31.2 \\
\hline & 7-11 yaş & 5 & 31.2 \\
\hline & $11-17$ yaş & 5 & 31.2 \\
\hline & $17-30$ yaş & 1 & 6.2 \\
\hline \multirow{3}{*}{ Çocuk Sayısı } & 1 çocuk & 5 & 31.2 \\
\hline & 2 çocuk & 5 & 31.2 \\
\hline & 3 ve üzeri & 6 & 37.5 \\
\hline \multirow{3}{*}{ Anne Yaş } & $20-30$ yaş & 5 & 31.2 \\
\hline & $30-40$ yaş & 6 & 37.5 \\
\hline & $40-50$ yaş & 5 & 31.2 \\
\hline \multirow{4}{*}{ Anne Büyüdüğ̈̈ Yer } & Köy & 4 & 25 \\
\hline & Kasaba & 2 & 12.5 \\
\hline & Şehir & 10 & 62.5 \\
\hline & Büyükşehir & - & - \\
\hline \multirow{4}{*}{ Anne Eğitim Durumu } & Okur-Yazar değil & - & - \\
\hline & İlkokul-Ortaokul & 8 & 50 \\
\hline & Lise & 7 & 43.7 \\
\hline & Üniversite & 1 & 6.2 \\
\hline \multirow{4}{*}{ Baba Eğitim Durumu } & Okur-Yazar değil & - & - \\
\hline & İlkokul-Ortaokul & 11 & 68.7 \\
\hline & Lise & 3 & 18.7 \\
\hline & Üniversite & 2 & 12.5 \\
\hline
\end{tabular}

\section{Veri Toplama Araçları}

Kişisel bilgi formu. Katılımcılar hakkında demografik bilgileri elde etmek için araştırmacılar tarafından hazırlanan bir kişisel bilgi formu kullanılmıştır. Bu formda katılımcıların yaşı, eğitim durumu, ailede özel gereksinimli çocuk sayısı, özel gereksinimli çocuğun yaşı, babanın eğitim durumu ve ailenin gelir düzeyi gibi demografik bilgileri elde etmeye yönelik sorular bulunmaktadır.

Durumluk-Sürekli Kaygı Envanteri. Araştırmada annelerin kaygı düzeyleri, Spielberger, Gorsuch, Lushene, Vagg ve Jacobs (1983) tarafindan geliştirilen, Öner ve Le Compte (1985) tarafindan Türkçe'ye uyarlanan Durumluk-Sürekli Kaygı Envanteri (State-Trait Anxiety Inventory) ile değerlendirilmiştir. Envanterde, yirmişer maddeden oluşan Durumluk Kaygı alt ölçeği ile Sürekli Kaygı alt ölçeği bulunmaktadır. Durumluk Kaygı Ölçeği, bireyin belli bir anda ve belirli koşullarda kendini nasıl hissettiğini belirler. Sürekli Kaygı Ölçeği ise bireyin içinde bulunduğu durum ve koşullardan bağımsız olarak, genellikle kendini nasıl hissettiğini değerlendirir. Durumluk Kaygı Ölçeği maddelerinde ifade edilen duygu ya da davranışlar, bireyin içinde bulunduğu durumu hissetme derecesine göre; (1) hiç, (2) biraz, (3) çok, (4) tamamıyla şıklardan biri işaretlenerek cevaplandırılır. Sürekli Kaygı maddelerinde ifade edilen duygu ya da davranışlar ise; sıklık derecesine göre; (1) hemen hiçbir zaman, (2) bazen, (3) çoğu zaman ve (4) hemen her zaman seçeneklerinden biri ile cevaplandırılır. Her iki ölçekten elde edilen toplam 
puan değeri 20 ile 80 arasında değişmektedir. Puanın yüksek olması kaygı düzeyinin yüksek olduğunu, puanın düşük olması ise kaygı düzeyinin düşük olduğunu ifade eder.

Durumluk-Sürekli Kaygı Envanteri’nin özgün formunun iç tutarlılık katsayıları .86 ile .95 arasında, test tekrar test güvenirliği ise .65 ile .75 arasında bulunmuştur (Spielberger ve diğ.,1983). Öner ve Le Compte (1985) tarafindan Türkçe'ye uyarlanan envanterin Türkçe formunun test tekrar test güvenirliği Sürekli Kayg Ölçeği için .71 ile .86, Durumluk Kaygı Ölçeği için .26 ile .68 arasında saptanmıştır. Kuder Richardson 20 formülüyle hesaplanan iç tutarlılık katsayısı ise, Durumluk Kaygı Ölçeği için .83 ile .87, Sürekli Kaygı Ölçeği için .94 ile .96 arasında olduğu gözlenmiştir.

Yaşam Doyumu Ölçeği. Çalışmaya katılan annelerin yaşam doyumlarını belirlemek üzere, Diener, Emmons, Larsen ve Griffin (1985) tarafindan geliştirilmiş olan ve Yetim (1991) tarafindan Türkçe'ye uyarlanan Yaşam Doyumu Ölçeği (Satisfaction with Life Scale) kullanılmıştır. Ölçek toplam beşmaddeden oluşmakta ve maddeler 7'li derecelendirme ile (hiç uygun değil=1, "uygun değil=2, biraz uygun değil=3, ne uygun ne uygun değil $=4$, biraz uygun $=5$, uygun $=6$, çok uygun $=7$ ) şeklinde yanıtlanmaktadır. Ölçekten alınabilecek en düşük puan beş, en yüksek puan ise $35^{\prime}$ tir. Ölçekten alınan düşük puanlar yaşam doyumunun düşük olduğunun, yüksek puanlar ise yaşam doyumunun yüksek olduğunun göstergesi olarak kabul edilmektedir. Diener ve diğerleri (1985) tarafindan geliştirilmiş olan Yaşam Doyumu Ölçeği'nin (Satisfaction with Life Scale) Cronbach alfa iç tutarlılık katsayıs1.87 ve test tekrar test güvenirliği .82 olarak bulunmuştur. Yetim (1991) tarafindan Türkçe'ye uyarlanan Yaşam Doyumu Ölçeği'nin iç tutarlılık katsayısı .86 ve test tekrar test güvenirliği .73 olarak saptanmıştır.

$\mathrm{Bu}$ araştırmada, durumluk kaygı .93; sürekli kaygı, .84 olarak saptanmıştır. Yaşam Duyumu ölçeğinin geçerliğinin ise .88 olduğu saptanmıştır.

\section{Uygulama Süreci}

Deney ve kontrol grubu olarak belirlenen annelerle uygulama öncesi tek tek görüşme yapılmış, araştırma hakkında genel bilgiler verilmiş ve katılım için onayları alınmışıı. Deney ve kontrol grubundaki annelere uygulama öncesi "Yaşam Doyumu Ölçeği” ve "Durumluk-Sürekli Kaygı Envanteri”" uygulanmıştır. Ayrıca grupla psikolojik danışma programı süreci ve genel kurallar hakkında deney grubundaki katılımcılara bilgi vermek için ön görüsşme yapılmıştır.

Bu çalı̧̧ada, deney grubunu oluşturan annelerle, sekiz oturumdan oluşan yarı yapılandırılmış grupla psikolojik danışma oturumları gerçekleştirilmiştir. Her oturum yaklaşık 65 dakika sürmüştür. Süreç haftada bir oturum yapılacak şekilde organize edilmiştir. Uygulama yeri olarak kurum psikoloğunun önerisi ile psikolog odası belirlenmiştir. Grupla psikolojik danışma uygulaması sürecinde kontrol grubuna herhangi bir uygulama yapılmamıştır. Uygulama sonrası hem deney hem kontrol grubundaki annelere "Yaşam Doyumu Ölçeği" ve "Durumluk-Sürekli Kaygı Envanteri” tekrar uygulanmıştır.

Uygulama sürecinde, birinci oturumda grup üyelerinin birbirleriyle tanışmasının ardından, grupta uyulması gereken kurallar belirlenmiştir. İkinci oturumda kaygı, stres ve endişe kavramları hakkında bilgiler sunulmuştur. Üçüncü oturumda annelerin, çocuklarının engelli olduklarını ilk öğrendiklerinde yaşamış oldukları yaşadıkları duygularını ifade edebilmelerine kabul, anlayış ve destek vererek grupta çalışılmıştır. Annelerin bu süreçte duygulandıkları, birbirlerine destek oldukları, grup desteği ile anneler yaşadıklarını, hissettiklerini paylaşmışlardır. Bununla birlikte annelerde duygu boşalması (katarsis) yaşadıkları gözlenmiştir. Dördüncü oturumda, toplumun özel gereksinimi olan çocuğa tutumu, bakış açısı ve algılayışı konusunda farkındalık üzerinde çalışılmıştır. Beşinci oturumda özel gereksinimi olan çocuğun doğumuyla aile ilişkilerinde yaşanan değişimler ve çocuğun eğitiminde aile desteğinin önemi üzerinde durulmuştur. Altınc1 oturumda "problem çözümünde zorunlu analiz tekniği" hakkında bilgi verilmiştir. Yedinci oturumda annelerin "problem çözümünde zorunlu analiz tekniği”ni kullanarak sorunlarını nasıl çözeceklerine dair uygulamalar yapılmıştır. Sekizinci oturumda, çalışma grubundaki annelerle birlikte oturumların genel değerlendirmesi yapılmıştır. 


\section{Verilerin Analizi}

Araştırmada deney ve kontrol grubu olmak üzere iki grup bulunmaktadır. Deney ve kontrol gruplarının ölçeklerden aldıkları puanların normal dağılım gösterip göstermediği Shapiro-Wilk testi ile incelenmiştir. Ayrıca, basıklık ve çarpıklık değerleri incelenmiştir.

Shapiro Wilk testi sonuçlarına göre farklı iki grupta yer alan katılımcıların durumluk-sürekli kaygı ve yaşam doyumu ön test-son test puanlarının ( $\mathrm{p}>0.05) \% 95$ güven aralı̆̆ında normal dağı̆lım gösterdiği gözlenmiştir. Ayrıca farklı iki grupta yer alan katılımcıların aldığı puan dağılımlarının basıklık ve çarpıklık değerlerinin -1.5 ve 1.5. arasında olduğu gözlenmiştir. Bu puan dağılımları, normal dağılım durumunu göstermektedir. Herhangi bir veri grubunda çarpıklık ve basıklık değerlerinin $+1,-1$ aralığında olmasının normal dağılım için genellikle kabul edilebilir değerler olmasına karşın, bu değerin $+2,-2$ aralı̆ıında olması da kabul edilebilir bir durum olarak görülmektedir (Cooper ve Cutting, 2010, Akt.; Arapkirlioğlu ve Tankız, 2011). Çalışmada gruplar-içi regresyon eğimlerinin homojen olduğu saptanmıştır ( $>>0.05$ ). Deney ve kontrol gruplarının durumluk kaygı, sürekli kaygı ve yaşam doyumu ön test puanlarının t-testi sonuçları Tablo 3 'te sunulmuştur.

Tablo 3

Deney ve Kontrol Gruplarının Durumluk Kaygl, Sürekli Kaygı ve Yaşam Doyumu Ön Test Puanlarının T-testi Sonuçları

\begin{tabular}{|c|c|c|c|c|c|c|}
\hline Değişkenler & $N$ & $\bar{X}$ & $S S$ & $S d$ & $t$ & $p$ \\
\hline \multicolumn{7}{|l|}{ Durumluk Kayg1 } \\
\hline Deney Grubu & 8 & 48.75 & 6.63 & 14 & 2.64 & .01 \\
\hline Kontrol Grubu & 8 & 38.13 & 9.18 & & & \\
\hline \multicolumn{7}{|l|}{ Sürekli Kayg1 } \\
\hline Deney Grubu & 8 & 51.13 & 5.27 & 14 & 2.40 & .03 \\
\hline Kontrol Grubu & 8 & 43.50 & 7.25 & & & \\
\hline \multicolumn{7}{|l|}{ Yasam Doyumu } \\
\hline Deney Grubu & 8 & 23.28 & 4.32 & 14 & -.431 & .67 \\
\hline Kontrol Grubu & 8 & 25.25 & 7.92 & & & \\
\hline
\end{tabular}

Tablo 3 incelendiğinde, grupların yaşam doyumu ön test puan ortalamaları arasında anlamlı fark bulunmamakla birlikte $(t(14)=-.431, p>.05)$ iki grubun durumluk $(t(14)=2.64, p<.05)$ ve sürekli kaygı ön test puan ortalamaları $(t(14)=2.40, p<.05)$ arasında anlamlı farklılıklar bulunduğundan, grupla psikolojik danışma programının etkililiğini belirlemek için grupların öntest puanları kontrol altında tutularak son test puanlarını karşılaş̧ıırmak için Kovaryans (ANCOVA) (Büyüköztürk, 2011) analizi yapılmıştır.

\section{Bulgular}

Bu bölümde, deney ve kontrol gruplarındaki annelerin Durumluk-Sürekli Kaygı Envanteri ve Yaşam Doyumu Ölçeği'nden aldıkları puanların analizi sonucunda elde edilen bulgulara yer verilmiştir. Deney ve kontrol gruplarının ön test ve son test puanlarının aritmetik ortalama ve standart sapmaları Tablo 4'te sunulmuştur. 
Tablo 4

Deney ve Kontrol Gruplarının Durumluk Kaygl, Sürekli Kaygl ve Yaşam Doyumu Ölçeği'nden Aldıkları ÖntestSontest Puan Ortalamalart ve Standart Sapma Değerleri

\begin{tabular}{ccccccc}
\hline Değişkenler & \multicolumn{2}{c}{ Öntest } & \multicolumn{2}{c}{ Sontest } \\
\hline Durumluk Kayg1 & $\mathbf{N}$ & $\overline{\mathbf{X}}$ & $\mathbf{S S}$ & $\mathbf{N}$ & $\overline{\mathbf{X}}$ & SS \\
Deney Grubu & 8 & 48.75 & 6.69 & 8 & 38.25 & 7.57 \\
Kontrol Grubu & 8 & 38.13 & 9.18 & 8 & 38.25 & 8.81 \\
\hline Sürekli Kayg1 & & & & & & \\
Deney Grubu & 8 & 51.13 & 5.27 & 8 & 39.50 & 6.59 \\
Kontrol Grubu & 8 & 43.50 & 7.25 & 8 & 44.25 & 8.94 \\
\hline Yaşam Doyumu & & & & & & \\
Deney Grubu & 8 & 23.88 & 4.32 & 8 & 28.13 & 4.05 \\
Kontrol Grubu & 8 & 25.25 & 7.92 & 8 & 26.38 & 5.92 \\
\hline
\end{tabular}

Tablo 4 incelendiğinde, deney ve kontrol gruplarının yaşam doyumu ön test puan ortalamaları arasında anlamlı bir farklılık bulunmamakla birlikte, grupların durumluk kaygı ve sürekli kayg1 ön test puan ortalamaları arasında anlamlı bir farklılık bulunduğundan, grupla psikolojik danışma uygulamasının annelerin durumluk kaygı, sürekli kaygı ve yaşam doyumları üzerindeki etkisini belirlemek için Kovaryans (ANCOVA) analizi yapılmıştır. $\mathrm{Bu}$ analiz için öncelikle ortak değişken (durumluk kayg1-DKÖN sürekli kayg1-SKÖN ve yaşam doyumu-YDÖN ön test puanları) ile bağımlı değişken (durumluk kayg1-DKSON, sürekli kaygı-SKSON ve yaşam doyumuYDSON son test puanları) arasındaki ilişkiyi incelemek amacıyla Pearson korelasyon katsayıları hesaplanmış ve sonuçlar Tablo 5'te sunulmuştur.

Tablo 5

Katılımcıların Durumluk-Sürekli Kaygı ve Yaşam Doyumu Ön test-Son test Puanlarının Korelasyon Analizi Sonuçları

\begin{tabular}{|c|c|c|c|c|c|c|}
\hline Değişkenler & YDÖN & YDSON & DKÖN & DKSON & SKÖN & SKSON \\
\hline YDÖN & 1 & & & & & \\
\hline YDSON & $.880^{*}$ & 1 & & & & \\
\hline DKÖN & $-.616^{*}$ & -.481 & 1 & & & \\
\hline DKSON & $-.510^{*}$ & $-.608^{*}$ & $.709^{*}$ & 1 & & \\
\hline SKÖN & $-.578^{*}$ & $-.593^{*}$ & $.756^{*}$ & $.525^{*}$ & 1 & \\
\hline SKSON & -.463 & $-.747^{*}$ & .380 & $.752^{*}$ & $.541^{*}$ & 1 \\
\hline
\end{tabular}

Tablo 5 incelendiğinde, yaşam doyumu ön test ile yaşam doyumu son test puanları arasında pozitif yönde anlamlı bir ilişki olduğu saptanmıştır. Durumluk kaygı öntest ile durumluk kaygı sontest arasında pozitif yönde anlamlı bir ilişki gözlenmiştir. Ayrıca, sürekli kaygı öntest ile sürekli kaygı sontest arasında pozitif yönde anlamlı bir ilişki olduğu gözlenmiştir.

Deney ve kontrol grubuna katılan annelerin durumluk kaygı, sürekli kaygı ve yaşam doyumu ön test puanlarına göre düzeltilmiş sontest puanları arasında anlamlı farklılık olup olmadığını incelemek amacıyla yapılan Kovaryans (ANCOVA) Analizi sonuçları Tablo 6'da sunulmuştur. 
Tablo 6

Grupların Ön Test Puanlarına Göre Düzeltilmiş Son Test Puanlarına ilişkin ANCOVA Sonuçları

\begin{tabular}{lccccc}
\hline Varyansın Kaynağı & Kareler Toplamı & Sd & Kareler Ortalaması & F & $p$ \\
\hline Durumluk Kaygı (Regresyon) & 711.657 & 1 & 711.657 & 39.64 & .00 \\
Grup & 237.000 & 1 & 237.000 & 13.20 & .00 \\
Hata & 233.343 & 13 & 17.949 & & \\
Toplam (düzeltilmiş) & 945.000 & 15 & & & .00 \\
\hline Sürekli Kaygı (Regresyon) & 675.234 & 1 & 675.234 & 46.62 & .00 \\
Grup & 485.851 & 1 & 485.851 & 33.54 & .00 \\
Hata & 188.266 & 13 & 14.482 & & .01 \\
Toplam (düzeltilmiş) & 953.750 & 15 & & & 74.06 \\
\hline Yaşam Doyumu (Regresyon) & 306.882 & 1 & 306.882 & 7.25 & \\
Grup & 30.041 & 1 & 30.041 & & \\
Hata & 53.868 & 13 & 4.144 & & \\
Toplam (düzeltilmiş) & 373.000 & 15 & & & \\
\hline
\end{tabular}

Tablo 6 incelendiğinde, grupların durumluk kaygı öntest puanına göre düzeltilmiş durumluk kaygı sontestpuan ortalamaları arasında anlamlı bir farkın olduğu saptanmıştır $\left(F_{(1-13)}=13.20, p<.05\right)$. Başka bir ifadeyle, grupla psikolojik danışma uygulamasının deney grubundaki katılımcıların durumluk kaygılarını anlamlı düzeyde azalttığı söylenebilir. Grupların sürekli kaygı öntest puanına göre düzeltilmiş sürekli kaygı sontestpuan ortalamaları arasında da anlamlı bir farkın olduğu gözlenmiştir $\left(F_{(1-13)}=33.54, p<.05\right)$. Başka bir ifade ile deney grubuna yapılan uygulama, bu gruptaki annelerinsürekli kaygılarını anlamlı düzeyde azaltmıştır. Ayrıca, grupların yaşam doyumuöntest puanına göre düzeltilmiş yaşam doyumusontestpuan ortalamaları arasında anlamlı bir farkın olduğu saptanmıştır $\left(F_{(1-13)}=7.25, p<.05\right)$. Başka bir ifadeyle, grupla psikolojik danışma uygulamasının deney grubundaki katılımcıların yaşam doyumlarını anlamlı düzeyde arttırdığı gözlenmiştir

\section{Tartışma}

$\mathrm{Bu}$ araștırmada, grupla psikolojik danışma programının özel gereksinimli çocuğa sahip annelerin durumluk-sürekli kaygılarını azaltmada ve yaşam doyumlarını artırmada etkili olup olmadığı incelenmiştir. Elde edilen bulgulara göre, grupla psikolojik danışma uygulamasına katılan annelerin durumluk-sürekli kaygılarında kontrol grubundaki annelere göre anlamlı düzeyde azalma olduğu gözlenmiştir. Bu sonucun deneysel uygulamanın etkisinden kaynaklandığı saptanmıştır. Diğer bir deyişle grupla danışma programının, özel gereksinimli çocukların annelerinin durumluk-sürekli kaygı düzeylerini azaltmada etkili bir yaklaşım olduğu saptanmıştır.

Alan yazın incelendiğinde, Cin ve Kılıç (2005) tarafından yapılan özel gereksinimli çocuğa sahip ebeveynlerin kaygılarını azaltmaya yönelik yaptıkları araştırmada, eğitsel ve psikolojik destek içerikli grup rehberliği programının özel gereksinimli çocuğa sahip anne babaların durumluk-sürekli kaygı düzeylerini azaltmada etkili olduğu saptanmıştır. Bu süreci destekleyen diğer bir araştırmada Kuloğlu (1992) tarafından yapılmıştır. Bilgi verici danışmalık programının otistik çocuğa sahip anne-babaların kaygı düzeylerini azaltmaya yönelik uygulandığı araştırmada, deney ve kontrol grupları arasında anlamlı bir farklılık saptanmıştır. Bulgumuzu destekleyen bir araştırmada, Yıldırım ve Conk (2005) tarafından yarı deneysel araştırma özel gereksinimli çocuğa sahip ebeveynlerle yapılmıştır. Araştırma sonucunda kontrol grubundaki ebeveynlerde kaygı düzeyi anlamlı bir farklılık görülmezken, deney grubundaki ebeveynlerin anlamlı bir şekilde azalmıştır. Programa katılan annelerin kaygı düzeylerinde görülen azalma Leung, Fan ve Sanders'ın (2013) yaptığı araştırmayla da tutarlıdır. Bu çalışmada, özel gereksinimli çocuğa sahip Çinli ailelerin ebeveyn eğitimi uygulaması sonrası kaygı puanlarının anlamlı olarak düştüğü belirlenmiştir. Buna göre, kaygı ile baş etme yöntemlerinin psikolojik danışma uygulaması veya eğitim ile azaltılması gerçekleştirilebilir.

$\mathrm{Bu}$ araştırmada elde edilen bir diğer bulguya göre de, grupla psikolojik danışma uygulamasının deney grubundaki annelerin yaşam doyumu puanları üzerinde anlamlı etkisi olduğu gözlenmiştir. Bu sonucun deneysel 
uygulamanın etkisinden kaynaklandığı söylenebilir. Diğer bir deyişle grupla danışma programının, annelerin yaşam doyumu düzeylerini artırmada etkili bir yaklaşım olabileceği ileri sürülebilir. İlgili alan yazın incelendiğinde, araştırma bulgumuz, Deniz ve diğerleri (2009) tarafindan yapılan benzer araştırma bulgularıyla örtüşmektedir. Dilmaç ve diğerlerinin (2015) araştırması ise, 293 kadın ve 119 erkek olmak üzere 407 ebeveyn ile gerçekleştirilmiştir. Araştırma sonucunda eğitim gruplarına katılan ebeveynlerin yaşam doyumu puanlarında anlamlı bir artış gözlenmiştir. Bu süreci destekleyen bir başka araştırmada, Bilge ve diğerleri (2014) tarafından yapılmışıır. Yarı deneysel tipteki bu araştırmanın örneklemini özel gereksinimli bireylerin araştırmaya katılmayı kabul eden aileleri oluşturmuştur. Araştırma bulgularına göre, özel gereksinimli bireylerin ailelerinin eğitim sonrası yaşam doyumlarının arttı̆̆ saptanmıştır. Kaner'in (2004) yılında 416 ebeveyn ile gerçekleştirdiği deneysel olmayan, kapsamlı araştırmasının daelde etmiş olduğumuz bulguyu destekleyen yönleri olduğu gözlenmiştir. Söz konusu araştırma sonucunda yaşam doyumunun tüm sosyal destek türleri ile ilişkilerinin olumlu yönde olduğu ve sosyal destek arttıkça yaşam doyumunun arttığı görülmüsştür. Yıldırım Doğru ve Arslan (2006) tarafindan gerçekleştirilen benzer bir araştırmada ise sürekli ile durumluk kaygı puanları arasında anlamlı bir ilişkiye rastlanamamıştır. Araştırmada zihinsel ve işitme engelli çocuğa sahip ailelerin kaygı düzeyleri ile yaşam kaliteleri karşılaştırılmış ve zihinsel engelli çocuğa sahip ailelerde kaygı düzeyinin daha yüksek olduğu, yaşam kalitesinin ise daha düşük olduğu gözlenmiştir. Dolayısıyla çocuklarda özel gereksinim düzeyleri arttıkça ailelerin kaygı düzeylerinin durumluk kaygıdan sürekli kaygı düzeyine evrilmesi mümkündür. Buna göre ailelere periyodik olarak psikolojik danışma hizmeti sunulması önerilebilir.

\section{Sonuç ve Öneriler}

Bu çalışmada özel gereksinimli çocuğa sahip annelere yönelik grupla psikolojik danışma uygulaması sonucunda annelerin psikolojik iyi oluş halinde ortaya çıkan olumlu gelişmelere karşın, zaman içerisinde ve karşılaşılan diğer yaşam sorunları ile birlikte annelerin yaşam doyumlarında azalma olması ve kaygılarının da artması beklenebilir. Dolayısıyla, özel gereksinimli çocuğun yaşından bağımsız olarak, annelerin zaman zaman bu tür destek hizmetlerine gereksinim duymaları mümkündür. Annelerin kendilerini yalnız ve çaresiz hissetmemeleri, yaşadıkları güçlüklerle daha etkili biçimde başa çıkabilmeleri, kaygıların azalması ve yaşam doyumlarının artması için ilgili kişi ve kurumlar tarafından profesyonel destek hizmetlerinin sağlanması önem taşımaktadır. Annelere, çevrelerindeki mevcut sosyal destek kaynaklarının neler olduğu, bunlara nasıl ulaşabilecekleri ve bunlardan etkili biçimde nasıl yararlanabilecekleri konusunda farkındalık kazandırılmalı ve bu sosyal desteklerden yararlanmaları desteklenmelidir.

$\mathrm{Bu}$ çalışmanın bazı sınırlılıkları bulunmaktadır. Bu sınırılıkları ve araştırmada elde edilen bulguları dikkate alarak uygulamaya ve ileri çalışmalara yönelik aşağıdaki önerilere yer verilebilir:

1. Bu araştırmada özel gereksinimli çocuğa sahip babalar uygulamaya dâhil edilmemiştir. Babalarla da ya da anne ve babaların birlikte katılacağı gruplarla psikolojik danışma uygulaması yapılabilir.

2. Grupla danışma uygulaması dışında, ihtiyaç duyan annelere ve babalara bireysel psikolojik danışma desteği verilebilir.

3. Bu çalışmada yürütülen psikolojik danışma uygulaması, uygulama süreci başlığı altında içeriği açıklanan ve sekiz oturumdan oluşan bir programdır. Özel gereksinimli çocuğa sahip ebeveynlerin kaygı düzeylerini azaltmaya yönelik farklı içeriğe sahip programlar geliştirilip uygulanabilir.

4. Özel gereksinimli çocukların devam ettikleri eğitim kurumlarındaki uzmanlar ebeveynlere yaşadıkları güçlüklerle daha etkili başa çıkmalarına yardımcı olmak üzere aile danışmanlığı uygulamaları yapabilirler.

5. Bu çalışmaya çeşitli yetersizlik gruplarından ve geniş bir yaş aralığındaki çocukların anneleri katılmıştır. Oysa farklı yetersizlik gruplarında ve farklı gelişim dönemlerinde çocuğu olan anne-babaların yaşadıkları güçlükler de farklılık gösterebilmektedir. Dolayısıyla ailelere yönelik psikolojik destek çalışmalarının, farklı ebeveyn grupları üzerindeki etkileri sonraki çalışmalarda daha ayrıntılı biçimde incelenebilir. 


\section{Kaynaklar}

Arapkirlioğlu, H., \& Tankız, K. D. (2011). Müzik öğretmenliği program özel yetenek sınavlarında alan ve yerleştirme puanlarının karşılaştııılması [Opinions of teachers, parents and principals regarding inclusive practices]. E-Uluslararası Ĕgitim Araştırmaları Dergisi, 2(4), 55-69.

Baker-Ericzén, M. J., Brookman-Frazee, L., \& Stahmer, A. (2005). Stress levels and adaptability in parents of toddlers with and without autism spectrum disorders. Research and Practice for Persons with Severe Disabilities, 30(4), 194-204.

Büyüköztürk, S. (2011). Sosyal bilimler için very analizi el kitabı: İstatistik, araștırma deseni, SPSS uygulamaları ve yorum (14. bask1) [A very analytical handbook for social sciences: Statistics, research desidence, SPSS practices and comments (14th edition)].Ankara: Pegem Yayınları.

Byrne, E. A., \& Cunningham, C. C. (1985). The effects of mentally handicapped children on families-a conceptual review. Journal of Child Psychology and Psychiatry, 26(6), 847-864.

Cameron, S. J., \& Armstrong, S., M. (1991). Stress, coping, and resources in mothers of adults with developmental disabilities. Counselling Psychology Quarterly, 4(4), 301-310.

Cameron, S. J., Dobson, L. A., \&Day, D. M. (1991). Stress in parents of developmentally delayed and non-delayed preschool children. Canada's Mental Health, 39(1), 13-17.

Cin, A. (2001). Grup rehberliğinin özürlü çocuğu olan anne babaların kaygı düzeylerinin azaltılmasındaki etkisi (Yayımlanmamış yüksek lisans tezi) [Impact of group guidance on reducing parental anxiety levels (Unpublished master's thesis)]. İnönü Üniversitesi, Sosyal Bilimler Enstitüsü, Malaty. http://tez.yok.gov.tr/UlusalTezMerkezi adresinden elde edilmiş̧ir. (Tez No. 107207)

Cin, A., \& Kılıç, M. (2005). Deneysel olarak sınanmış grupla psikolojik danışma ve rehberlik programları 2. S. Erkan \& A. Kaya (Eds.), Özürlü çocuğu olan anne babaların kaygı düzeylerini azaltmaya yönelik bir grup rehberliği uygulaması (ss. 70-102) [A group guidance practice to reduce the anxiety levels of parents with disabilities (pp. 70-102)]. Ankara: Pegem-A Yayıncılık.

Deniz, M. (2006). The relationships among coping with stress, life satisfaction, decision-making styles and decision self-esteem: An investigation with Turkish university students. Social Behavior and Personality: An International Journal, 34(9), 1161-1170.

Deniz, M. E., Dilmaç, B., \&Arıcak, O. T. (2009). Engelli çocuğa sahip olan ebeveynlerin durumluk-sürekli kaygı ve yaşam doyumlarının incelenmesi [Examining the state-trait anxiety and life satisfaction of parents with a disabled child]. Uluslararası Insan Bilimleri Dergisi, 6(1), 953-968.

Diener, E. D., Emmons, R. A., Larsen, R. J., \& Griffin, S. (1985). The satisfaction with life scale. Journal of Personality Assessment, 49(1), 71-75.

Dilmaç, B., \& Ekşi, H. (2008). Investigation the relationship between life satisfaction and self esteem among vocational schools students. Selcuk University the Journal of Institute of Social Sciences, 20, 279-289.

Dilmaç, B., Çıkııı, Y., Koçak, F., \& Çalıkçı, M. (2015). Zihinsel engelli çocuğa sahip olan annelerin kaygı düzeylerini azaltıcı eğitim programının annelerin durumluk ve sürekli kaygı düzeylerine etkisi [Impact of mothers with mentally retarded children's anxiety levels on their mothers' state and trait anxiety levels]. Dumlupinar Üniversitesi Sosyal Bilimler Dergisi, 24, 65-71.

Erol, N., \& Öner, Ö. (1999). New approaches to anxiety. Turkish Journal of Child and Adolescent Mental Health, $6(1), 52-60$. 
Ersanlı, K., \& Kutlu, M., (1998). Zihinsel engelli çocuğu olan annelerin umutsuzluk düzeyleri [Hopelessness levels of mothers with mental retardation]. VII. Ulusal Eğitim Bilimleri Kongresi Bildiriler Kitab1, 1, 341-348.

Ersoy, Ö. \& Güneysu, S. (1998). Destekleyici eğitim programlarının engelli çocuğu olan anneler üzerindeki etkisi [The impact of supporting educational programs on mothers with disabilities]. Ankara: Konak Kirtasiye.

Esdaile, S. A., \& Greenwood, K. M. (2003). A comparison of mothers' and fathers' experience of parenting stress and attributions for parent-child interaction outcomes. Occupational Therapy International, 10(2), 115126.

Fışıloğlu, A., \& Fışıloğlu, H. (1997). İşitme engelli bireyile değişim sürecindeki ailelerin karşılaştıkları sorunlar. N. Karanc1 (Ed.), Farklllıkla yaşamak: Aile ve toplumun farkl gereksinimleri olan bireylerle birlikteliğ $i$ içinde (ss. 23-35) [Living with diversity: In the coexistence of family and society with individuals with different needs (pp. 23-35)]. Ankara: Türk Psikologlar Derneği Yayınları.

Gallagher, J. J., Beckman, P., \& Cross, A. H. (1983). Families of handicapped children: Sources of stress and its amelioration. Exceptional Children, 50(1), 10-19.

Hastings, R. P. (2003). Child behaviour problems and partner mental health as correlates of stress in mothers and fathers of children with autism. Journal of Intellectual Disability Research, 47(45), 231-237.

Kaner, S. (2004). Engelli çocukları olan ana babaların algıladıkları stres, sosyal destek ve yaşam doyumları [Stress, social support and life satisfaction perceived by parents with handicapped children], Yayınlanmamış Araştırma Raporu, Ankara Üniversitesi Bilimsel Araştırma Projeleri, Ankara.

Karasar, N. (2015). Bilimsel araştırma yöntemi: Kavramlar, ilkeler, teknikler (28.baskı) [Scientific research method: Concepts, principles, techniques (28th edition)]. Ankara: Nobel Yayın Dağıtım.

Kazak, A. E., \& Marvin, R. S. (1984). Differences, difficulties and adaptation: Stress and social networks in Families with a handicapped child. Family Relations, 33(1), 67-77.

Koçoğlu, D. (2006). Konya kent merkezinde să̆lıklı yaşam biçimi davranışları ve yaşam kalitesinde să̆llkta sosyoekonomik eşitsizlikler (Yayımlanmamışyüksek lisans tezi) [Healthy lifestyle behaviors in Konya city center and socioeconomic inequalities in health in life quality (Unpublished master thesis)]. Selçuk Üniversitesi Sağlık Bilimleri Enstitüsü, Hemşirelik Anabilim Dalı Halk Sağlığı Hemşireliği Bilim Dalı, Konya, Türkiye). http://tez.yok.gov.tr/UlusalTezMerkezi adresinden elde edilmiştir.

Köker S. (1991). Normal ve sorunlu ergenlerin yaşam doyumu düzeylerinin karşılaştırılması (Yayınlanmamış yüksek lisans tezi) [Comparison of life satisfaction levels of normal and problematic adolescents (Unpublished master thesis)]. Ankara Üniversitesi, Sosyal Bilimler Enstitüsü, Ankara. http://tez.yok.gov.tr/UlusalTezMerkezi adresinden elde edilmiştir. (Tez No. 16802)

Kuloğlu, N. (1992). Bilgi verici danışmanlı̆̆ın otistik çocuğu olan anne-babaların kaygl düzeylerine etkisi (Yayımlanmamıs yüksek lisans tezi) [Informative counseling is a test of the anxiety levels of parents with autistic children (Unpublished master's thesis)]. Ankara Üniversitesi, Sosyal Bilimler Enstitüsü, Eğitimde Psikolojik Hizmetler Anabilim Dalı, Ankara. http://tez.yok.gov.tr/UlusalTezMerkezi adresinden elde edilmiştir. (Tez No. 20767)

Kuzgun, Y., \& Hamamc1, Z. (2007). Ana-baba eğitim programlarl [Parent education programs]. Ankara: Maya AkademiYayınları.

Küçüker, S. (1993). Özürlü çocuk ailelerine yönelik psikolojik danışma hizmetleri [Psychological counseling services for disabled children's families]. Ankara Üniversitesi Ĕ̆itim Bilimleri Fakültesi Özel Ĕ̆itim Dergisi, 1(3), 23-29. 
Leung, C., Fan, A., \& Sanders, M. R. (2013). The effectiveness of a group triple with Chinese parents who have a child with developmental disabilities: A randomized controlled trial. Research in Developmental Disabilities, 34(3), 976-984.

Öner N. (1997). Psikolojik testler (3. baskı) [Psychological tests (3rd edition)]. İstanbul: Boğaziçi Üniversitesi Yayınları.

Öner, N., \& Le Compte, W. A. (1985). Durumluk-sürekli kayg lenvanteri el kitabı [State-trait anxiety inventory handbook]. İstanbul: Boğaziçi Üniversitesi Yayınları.

Özokçu, O., \& Canpolat, M. (2013). Grup rehberliği programının zihinsel yetersizliği olan çocuğa sahip annelerin stres düzeylerine etkisi [The effect of the group guidance program on the stress levels of mothers with mental retardation]. Mustafa Kemal Üniversitesi Sosyal Bilimler Enstitüsü Dergisi, 10(24), 181-196.

Sarason, I. G. (1988). Anxiety, self-preoccupation and attention. Anxiety Research, 1(1), 3-7.

Spielberger, C. D., Gorsuch, R. L., Lushene, R., Vagg, P. R., \& Jacobs, G. A. (1983). Manual for the State-Trait Anxiety Inventory. Palo Alto, CA: Consulting Psychologists Press.

Tamer, M. (2010). Zihinsel engelli çocuk annelerinde stress yönetimi eğitiminin etkileri (Yayımlanmamış yüksek lisans tezi) [The effects of stress management training in mothers with mental retardation (Unpublished master thesis)]. Ege Üniversitesi, Sosyal Bilimler Enstitüsü, İzmir. http://tez.yok.gov.tr/UlusalTezMerkeziadresinden elde edilmiştir. (Tez No. 262143)

Uğuz, Ş., Toros, F., İnanç, B. Y., \& Çolakkadıŏglu, O. (2004). Zihinsel ve/veya bedensel engelli çocukların annelerinin anksiyete, depresyon ve stres düzeylerinin belirlenmesi [Determination of anxiety, depression and stress levels of mothers of mentally and physically handicapped children]. Klinik Psikiyatri, 7(1), 4247.

Voltan-Acar, N. (2015). Grupla psikolojik danışma: Illke ve teknikleri (11. baskı) [Group counseling: Principles and techniques (11th edition)]. Ankara: Nobel Yayın.

Yetim, Ü. (1991). Kişisel projelerin organizasyonu ve örüntüsü açısından yaşam doyumu (Yayımlanmamış doktora tezi) [Life in terms of organization and pattern of personal projects (Unpublished doctoral dissertation)]. Ege Üniversitesi, Sosyal Bilimler Enstitüsü, İzmir. http://tez.yok.gov.tr/UlusalTezMerkezi adresinden elde edilmiştir. (Tez No. 16120)

Yıldırım, F., \& Conk, Z. (2005). Zihinsel yetersizliği olan çocuğa sahip anne/babaların stresle başa çıkma tarzlarına ve depresyon düzeylerine planlı eğitimin etkisi [The effect of planned education on the ways in which parents have children with mental disabilities and their depression levels]. Cumhuriyet Üniversitesi Hemşirelik Yüksekokulu Dergisi, 9(2), 1-10.

Yıldırım Doğru, S. S., \& Arslan, E. (2008). Engelli çocuğu olan annelerin sürekli kaygı düzeyi ile durumluk kaygı düzeylerinin karşılaştırılması [Comparison of levels of trait anxiety and level of trait anxiety for mothers with disabilities]. Selçuk Üniversitesi Sosyal Bilimler Enstitüsü Dergisi, 19(2008), 543-553.

Wishart, M. C., Bidder, R. T., \& Gray, O. P. (1981). Parents' report of family life with a developmentally delayed child. Child: Care, Health and Development, 7(5), 267-279. 


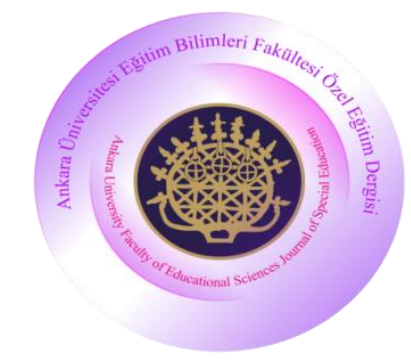

RESEARCH

\section{Ankara University Faculty of Educational Sciences Journal of Special Education}

Year: 2018, Volume: 19, Number: 2, Page No: 257-275

DOI: 10.21565/ozelegitimdergisi.372512

\title{
Analysis of the Effect of the Group Psychological Counseling Program on Anxiety Levels and Life Satisfaction Levels of Mothers with a Child with Special Needs*
}

\author{
Nermin Çiftçi Arıdă \\ Yıldız Technical University
}

\author{
Eyüp Sabır Erbiçer ${ }^{(i) * *}$ \\ Y1ldız Technical University
}

\begin{abstract}
The study was carried out with mothers who had children with special needs between the ages 3-17 and who attended a private rehabilitation center under the Ministry of National Education. A total of 16 mothers, 8 in the experimental group and 8 in the control group, participated in the study in which the pretest-posttest control group experimental model was used. The group psychological counseling program consisting of 8 sessions were implemented on the mothers in the experimental group. The data were collected through the State-Trait Anxiety Inventory and the Satisfaction with Life Scale. Analysis of Covariance (ANCOVA) was used in analyzing the data. It was observed that, as a result of the group psychological counseling program, there was a significant decrease in the state-trait anxiety scores and an increase in the life satisfaction levels of the mothers in the experimental group.
\end{abstract}

Keywords: Group psychological counseling, anxiety, state anxiety, trait anxiety, life satisfaction, mothers of children with special needs, children with special needs.

\section{Recommended Citation}

Çiftçi Arıdağ, N., \& Erbiçer, E. S. (2018). Analysis of the effect of the group psychological counseling program on anxiety levels and life satisfaction levels of mothers with a child with special needs. Ankara University Faculty of Educational Sciences Journal of Special Education, 19(2), 257-275. doi: 10.21565/ozelegitimdergisi.372512

\footnotetext{
${ }^{*}$ This article was presented as a poster at the $9^{\text {th }}$ Turkish-German Psychiatry Congress, September 14-17, 2016.

${ }^{* *}$ Corresponding author: Assist. Prof., E-mail: nermin_ciftci@ yahoo.com, https://orcid.org/0000-0002-1993-8352

${ }^{* * *}$ Res. Assist., E-mail: sabirerbicer@hotmail.com, https://orcid.org/0000-0001-8253-7212
} 
In all societies children are seen as adults of the future and cultivated with care. Families try to use their possibilities at the highest level for their children. It is important that children meet their needs during the growth process. With the understanding of the pregnancy of the mother, an intensive preparation for the individual will start. In common with all the different attitudes and habits in society, the common point is the encouragement shown to the mother for the health of the child. Along with the birth of the child, the life of the family will gain a new direction (Yıldırım Doğru and Arslan, 2008). While the family is expecting a healthy child, the special need of the child will change all expectations of the family. Families of children with special needs have various difficulties due to the specific problems and needs of their children (Gallagher, Beckman and Cross, 1983), in addition to the pressures and tensions that other families face. Families may be insufficient to cope with this intense stressful, long-term problem and experience various emotional and behavioral problems (Yildırım and Conk, 2005). Studies in the field reveal that parents of children with special needs have more anxiety than other parents (Dilmaç, Çıkılı, Koçak and Çalıkçı, 2015; Esdaile and Greenwood, 2003; Hastings, 2003, Uğuz, Toros, İnanç and Çolakkadıŏlu, 2004).

Öner (1997) defines anxiety as a mood that is perceived by the individual as dangerous or threatening, connected to an environmentally stimulating stimulus that the effects are not pleasant. According to Erol and Öner (1999), anxiety is widespread, disturbing and continuous. Clearly the cause cannot be determined and controlled. The beginning and ending are not obvious. State anxiety is the subjective fear that an individual feels due to the anxious state she or he is in. Physiologically, physical changes such as sweating, swelling, reddening and trembling are signs of the individual's feelings of tension and restlessness, an arousal in the autonomic nervous system. Continuous anxiety is the tendency of the individual for anxiety. This may also be referred as to a tendency to perceive situations in which a person is often stressful or anxious. Disappearing dissatisfaction is defined as trait anxiety when neutral conditions are perceived as dangerous and self-threatening by the individual. Individuals with such high level of anxiety can easily be inclined to be pessimistic (Öner and Le Compte, 1985). According to Sarason (1988), anxiety expresses the feelings of anxiety, indecision, confusion, fear, pessimism and hopelessness as a reaction to situations in which the individual feels insecure, and thus can negatively affect the individual's well-being from physical, emotional and social aspects.

Life satisfaction, considered as one of the ultimate goals of people and considered as a sub-dimension of happiness, is an important factor affecting the quality of life positively or negatively, parallel to the quality of life. In this sense, physical functions, psychological states, social relations within and outside the family, social environment interactions and beliefs play an important role in life satisfaction (Dilmaç and Ekşi, 2008). It is also an important sign of life satisfaction that living conditions are good, that the individual feels happy and that she / he can continue her / his life without being dependent on others and reach the comfort of life. In life satisfaction, individuals do not just improve their lifestyles and quality. In addition, there are possible situations that may affect the individual psychologically and economically. The quality of life of family members who are under the responsibility of the person is also an important influence on life satisfaction. Life satisfaction generally refers to the person's whole life and all dimensions of this life, as well as happiness, morality, and goodness (Koçoğlu, 2006). According to Köker (1991), life satisfaction is the emotional response or attitude of an individual to work, leisure, and other time periods. Life satisfaction is related to the age, gender, working and working conditions, level of education, income level, family life, social life, personality traits and biological factors. According to Deniz (2006), healthy decision-making and dealing with anxiety can increase the level of life satisfaction. In the study conducted by Bilge et al. (2014), it is seen that as anxiety decreases, life satisfaction increases. Furthermore, Kaner (2004) stated that life satisfaction is related to different types of social support, that parents have support that facilitates their lives, and that their life satisfaction is higher and their worries are less.

Due to the reasons mentioned above, families with children with special needs need psychological and social support more than other families (Cin and Kılıç, 2005). Social support services are an important factor in reducing family distress and increasing life satisfaction (Cameron and Armstrong, 1991; Kaner, 2004). Assistance services to be provided to families can contribute to the emotions, thoughts, perceptions and expectations of parents 
of children with special needs, to accept their children and to begin to hope for a better future in a realistic way (Ersanlı and Kutlu, 1998). It has been found that social support services provide a significant decline in the distress of families of children with special needs (Cin, 2001, Ersoy and Güneysu, 1998; Tamer, 2010). In Deniz, Dilmaç and Aricak (2009) study, it was observed that mothers of children with special needs who participated in the support group had lower levels of anxiety and higher levels of life satisfaction.

For the reasons mentioned above we worked with mothers of children with special needs. In this context, consultation with the mother and the eight-session group was conducted. Our aim is to bring together mothers of children from different groups of disabilities to ensure that mothers support each other with group dynamics and empathy. In this context, counseling with the group was conducted in groups with psychological counseling sessions to support the mothers' achievement, regardless of the level of disability and type of the disability of the child. In the current study, the main purpose of the psychological counseling program with the group to be applied to mothers of children with special needs is to reduce the state-trait anxiety levels of mothers and increase their life satisfaction.

In accordance with the general purpose of this study, the following hypotheses were tested:

- When state anxiety pre-test scores are controlled for, the mean post-anxiety anxiety scores of mothers who have and have not participated in the group psychological counseling program are significantly different.

- When the continuous anxiety pre-test scores are controlled for, the average of the post-task anxiety scores of the mothers who have and have not participated in the group psychological counseling program is significantly different.

- When the life satisfaction pre-test scores are controlled for, the satisfaction score of the mothers who have and have not participated in the group counseling program is significantly different.

\section{Method}

In this study, the effects of a psychological counseling program on state-trait anxiety and life satisfaction of mothers of children with special needs were examined. Experimental model with pre-test-post-test control group was used in the study (Karasar, 2015). The research was carried out in 2016 in a province of Istanbul with mothers of children with special needs, attending a special special education and rehabilitation center affiliated with the Ministry of National Education.

"State-Trait Anxiety Inventory" and "Life Satisfaction Scale" were completed by the mothers who wanted to participate in the group psychological counseling program for the formation of the study group. Experimental and control groups were created by means of unselected assignment method among 16 mothers having the highest score in "State-Trait Anxiety Inventory" and the lowest score in "Life Satisfaction Scale" (8 in each group). The psychological counseling practice for the mothers in the experimental group was carried out by the second author, a graduate student, under supervision of the first author under the "Group Counseling Practices" course. The number of the mothers who would participate in the group psychological counseling program was determined by the proposal about the group formation of 7-12 members in the process of becoming the group leader experience for the graduate and doctoral students proposed by Voltan-Acar (2015) was taken into consideration. A personal information form prepared by the researchers was used to obtain demographic information about the participants. In this form, there are questions about demographic information such as the age of the participants, educational status, the number of children with special needs in the family, the age of the child with the special needs, the educational status of the father, and the income level of the family. The levels of anxiety in the mothers were assessed by State Trait Anxiety Inventory developed by Spielberger, Gorsuch, Lushene, Vagg and Jacobs (1983) adapted by Öner and Le Compte (1985) into Turkish. In the inventory, there are State Anxiety Scale and Continuous Anxiety Scale which have 20 items in total. The Situational Awareness Scale determines how a person 
feels in a particular situation and on certain conditions. The Trait Anxiety Scale assesses how you feel about yourself, regardless of the circumstances and conditions of the individual. The emotions or behaviors expressed in the Situational Awareness Inventory are based on the number of emotions in the individual that can be marked as (1) no, (2) slightly, (3) very, (4). Emotions or behaviors expressed in Trait Anxiety items; frequency according to degree; (1) almost never answered, (2) sometimes, (3) often, and (4) almost always. The total score from both scales range from 20 to 80 . A high score indicates that anxiety level is high, while a low score indicates low level of anxiety. The internal consistency coefficients of the original form of State-Trait Anxiety Inventory ranged from .86 to .95 and the test retest reliability ranged from .65 to .75 (Spielberger et al., 1983). Test retest reliability of the Turkish version of the Inventory adapted by Turkish version by Öner and Le Compte (1985) was between .71 and .86 for the Trait Anxiety Scale and between .26 and .68 for the Situational Anxiety Scale. The internal consistency coefficient calculated by Kuder Richardson 20 formula was found to be between .83 and .87 for the State Anxiety Scale and between .94 and .96 for the Trait Anxiety Scale.

The Satisfaction with Life Scale developed by Diener, Emmons, Larsen and Griffin (1985) and adapted to Turkish by Yetim (1991) was used to determine the life satisfaction of the mothers participating in the study. The scale consists of a total of five items and the items are rated with a rating of 7 (not at all suitable $=1$, very suitable 7). The lowest score that can be taken from the scale is five, the highest score is 35 . Low scores on the scale are considered low life satisfaction and high scores are considered indicators of high life satisfaction. The Cronbach alpha internal consistency coefficient of the Satisfaction with Life Scale developed by Diener et al. (1985) was .87 and the test retest reliability was .82. The internal consistency coefficient of the Life Satisfaction Scale adapted to Turkish by Yetim (1991) was .86 and the test retest reliability was .73. In this study, the reliability of the state anxiety is .93; continuous anxiety is .84, and the Life Satisfaction scale is .88.

Individual interviews were made with the parents who were determined as experimental and control groups before implementation, general information about the research was given and approval for participation was taken. The "Life Satisfaction Scale" and the "State-Trait Anxiety Inventory" were applied to the mothers in the experimental and control groups before implementation. In addition, a preliminary interview was conducted with the group to provide information on participants in the experimental group on the psychological counseling program process and general rules. In this study, with the mothers in the experimental group psychological counseling sessions were held with semi-structured group format that lasted eight sessions. Each session lasted approximately 65 minutes. The process was organized in a way that a session was held once a week. The place of application was determined by the recommendation of the institution's psychologist as the office of the psychologist. In the process of psychological counseling with the group, no implementation was conducted with the control group. After the implementation, the "Life Satisfaction Scale" and "State-Trait Anxiety Inventory" were applied again to the mothers in both experimental and control groups.

In the implementation process, after the group members met each other in the first session, the rules to be fulfilled in the group were determined. The second session provided information on anxiety, stress, and anxiety. At the third session, the mothers worked on the feelings that they felt when they learned that their child had a disability with showing acceptance, understanding, and support from the group. They shared their feelings, by showing support for each othe. However, it was observed that the mothers had catharsis. At the fourth session, the awareness of the attitude, perspective and perception of the child with special needs of the community was examined. The fifth session focused on changes in family relationships that were important in the birth of the child with special needs and in the education of the child through the family education. At the sixth session, information was provided about "the analytical technique required for problem solving." In the seventh session, applications were made on how to solve problems using "analytical technique required for problem solving." At the eighth session, a general evaluation of the sessions with the parents in the group was made. There were two groups in the research; experiment and control group. The Shapiro-Wilk test was used to examine whether the scores of the experimental and control groups were normal. In addition, the values of kurtosis and skewness were examined. According to the results of Shapiro Wilk test, the state-trait anxiety and life satisfaction pre-test-post-test scores 
(p>.05) of participants in two different groups showed normal distribution in 95\% confidence interval. It was also observed that the ratios and skewness scores of the participants in the two different groups were between -1.5 and 1.5. These point distributions show the normal distribution. Although it is generally acceptable for the normal distribution to have skewness and kurtosis values in the range of $+1,-1$ in any data group, this value is considered to be acceptable in the range of +2, -2 (Cooper and Cutting, 2010; as cited by Arapkirlioğlu and Tank1z, 2011). The intra-group regression slopes of the study were found to be homogeneous $(p>.05)$.

\section{Results}

In this study, it was examined whether the group psychological counseling program implemented with mothers of children with special needs were effective in reducing state-continuing anxiety and increasing life satisfaction. According to the findings, it was observed that the state-continuing worries of the mothers participating in the psychological counseling with the group decreased significantly compared to the mothers in the control group. This result was attributed to the influence of the experimental application. In other words, the group counseling program was found to be an effective approach to reduce the state-trait anxiety levels of mothers of children with special needs.

When the literature was examined, in a study in which reducing the state-trait anxiety of mothers of children with special needs that was implemented by Cin and Kılıç (2005), it was determined that the group guidance program with educational and psychological support was effective in reducing the state-trait anxiety levels of parents of children with with special needs. Another research supporting this process was done by Kuloğlu (1992). A significant difference was found in anxiety levels between the experimental and control groups in the informative counseling program in which the parents of children with autism spectrum disorders participated. In a research study supporting our data, semi-experimental research by Yıldirım and Conk (2005) was conducted with parents of children with special needs. As a result of the study, the anxiety levels of the parents in the experimental group decreased significantly while the level of anxiety of mothers in the control group did not show any significant difference. The decrease in anxiety levels of the mothers participating in the program is also consistent with the research done by Leung, Fan and Sanders (2013). In that study, it was determined that Chinese parents of children with special needs had significantly lower levels of anxiety scores after parental education. Accordingly, it is possible to reduce the ways of coping with anxiety through psychological counseling or education. According to another finding obtained in this study, it was observed that psychological counseling with group had a significant effect on life satisfaction scores of the mothers in the experimental group. It can be said that this result is due to the effect of experimental implementation. In other words, it can be argued that the group counseling program may be an effective approach to increase the life satisfaction levels of the mothers. When the relevant field is examined in the literature, our research findings are in agreement with similar research findings made by Deniz and others (2009). The research of Dilmaç and others (2015) was conducted with 407 parents, 293 female and 119 male. As a result of the research, the life satisfaction scores of the parents who participated in the education groups increased significantly. In another research supporting this process, it was done by Bilge et al (2014). The sample of this semi-experimental type of study consisted of families who agreeded to participate in the research related to individuals with special needs. According to research findings, life satisfaction of families of individuals with special needs increased after education. It is observed that Kaner's (2004) non-experimental, extensive research with 416 parents supports the findings that we have dated. As a result of this study, it was seen that life satisfaction was positively related to all types of social support and life satisfaction increased as social support increased. In a similar research conducted by Yıldırım Doğru and Arslan (2006), no significant relationship was found between continuity and state anxiety scores. In the study, the levels of anxiety and quality of life of families of children with intellectual disabilities and hearing impairments children were compared and it was observed that the level of anxiety and quality of life were lower in families of children with intellectual disabilities. Therefore, it is possible for families to evolve their anxiety levels from state anxiety to continuing anxiety levels as their special needs increase. Accordingly, it may be advisable to provide psychological counseling services periodically to the families. 


\section{Discussion and Conclusion}

Despite positive developments in mothers' psychological well-being as a result of psychological counseling with a group of mothers of children with special needs in this study, it may be expected that the mothers' life satisfaction decreases and their anxieties increase with time and with other life problems encountered. Therefore, independent of the age of the child with a special need, it is possible for the mother to require such support services from time to time. It is important to provide professional support services by the individuals and institutions that help them feel less lonely and helpless, able to cope with difficulties, reduce their anxieties and increase their life satisfaction. Mothers should be aware of, and should be encouraged to benefit from the social support resources available in their environment, how they can be reached and how to benefit effectively from them.

This study has some limitations. Taking into account these limitations and findings of the study, the following proposals for implementation and further studies may be included:

1) Fathers of children with special needs were not included in this study. Psychological counseling can be done with groups of parents or parents to join together.

2) Apart from counseling with the group, the mother and the father can be given individual psychological counseling support.

3) The psychological counseling application carried out in this study is a program consisting of eight sessions, which is explained under the application process title. Programs with different contents can be developed and implemented to reduce the anxiety levels of parents of children with special needs.

4) Specialists in educational institutions where children with special needs attend may apply family counseling to help parents cope with the difficulties they experience.

5) This study included mothers of children with various disabilities and mothers of children with a large age range. However, the difficulties that parents with children have in different disability groups and in different developmental periods may also vary. Therefore, the psychological support activities for families, the effects on different parental groups can be examined in more detail in subsequent studies. 